\title{
CAKRAM
}

\section{KAJIAN TERHADAP BESARAN DAYA DAN EFISIENSI ALAT PERANGKAT GENERATOR HHO SEDERHANA TIPE DRY CELL SEBAGAI BAHAN PADUAN PEMBAKARAN DALAM PADA KENDARAAN BERMOTOR}

\author{
Rahmat Dadang ${ }^{1}$ \\ ${ }^{1}$ Program Studi Teknik Mesin, Universitas Pamulang \\ Jl. Surya Kencana No 1, Tangerang Selatan, 15417 \\ Email - rahmat.dadang@yahoo.com
}

Masuk : 28 Februari 2018 Direvisi : 26 Maret 2018 Disetujui : 4 April 2018

\begin{abstract}
Abstrak: Penelitian ini bertujuan untuk mengetahui terhadap besaran daya dan efisiensi alat perangkat generator HHO sederhana tipe dry cell sebagai bahan paduan pembakaran dalam pada kendaraan bermotor. Metode yang dilakukan dengan mempergunakan proses elektrolisis. Elektrolisis adalah pengurangan suatu elektrolit oleh arus listrik pada sel-sel elektrolisis, dimana molekul air $\left(\mathrm{H}_{2} \mathrm{O}\right)$ menjadi molekul hidrogen dan oxigen (HHO) yang menggunakan arus listrik dalam larutan elektrolit. Proses ini terjadi pada susunan plat dengan ukuran dan ruas kisi-kisi yang telah ditentukan. Jumlah plat ada sebelas, dan hanya dua plat yang diberikan hantaran arus listrik langsung pada baterai DC dikutub positif dan negative. Dari dua kutub tersebut terjadi reaksi reduksi (katoda) dan reaksi oksidasi (anoda) dalam air yang di alirkan arus listrik langsung mengalir melalui sistem. Dalam penelitian ini gas hidrogen dan oksigen dihasilkan, dan laju produksi HHO meningkat serta kecepatan arus listrik yang dibutuhkan dalam proses elektrolisis.
\end{abstract}

Kata kunci: Brown’s Gas, Elektrolisis, besaran daya dan efisiensi generator gas HHO.

Abstract:This research aims to determine the magnitude of power and efficiency of HHO generator device simple dry cell type as a material of internal combustion in motor vehicles. The method is performed by using electrolysis process. Electrolysis is the reduction of an electrolyte by electric current in electrolysis cells, wherein water molecule $(\mathrm{H} 2 \mathrm{O})$ becomes hydrogen and oxygen (HHO) molecule using electric current in electrolyte solution. This process occurs on the plate arrangement with the size and segment of the grating that has been determined. The number of plates is eleven, and only two plates given direct electric current on DC batteries are positive and negative. From these two poles the reduction reaction (cathode) and oxidation reaction (anode) occurs in the flow of electricity flowing directly through the system. In this study hydrogen and oxygen gas is generated, and the rate of HHO production increases as well as the velocity of the electrical current required in the electrolysis process.

Keywords: Brown's Gas, Electrolysis, power quantity and efficiency of HHO gas generator

\section{PENDAHULUAN}

Produksi hidrogen elektrolit telah dipelajari secara ilmiah selama lebih dari satu abad[1,2].Sejarah elektrolisis air dimulai sejak revolusi industri pertama, pada tahun 1800, ketika Nicholson dan Carlisle adalah orang pertama yang menemukan kemampuan pembedahan air elektrolitik. Pada tahun 1902 lebih dari 400 unit elektrolisis air industri beroperasi dan pada tahun 1939, sebuah pabrik elektrolisis air besar pertama dengan kapasitas $10.000 \mathrm{Nm} 3 \mathrm{H} 2$ / jam mulai beroperasi. Pada tahun 1948, electrolyser industri bertekanan pertama diproduksi oleh Zdansky/Lonza. Pada tahun 1966, sistem elektrolit polimer padat pertama (SPE) dibangun oleh General Electric, dan pada tahun 1972 unit elektrolisis air oksida padat pertama dikembangkan. Sistem alkalin maju pertama dimulai pada tahun 1978. Sejarah berakhir pada hari-hari kita dengan perkembangan membran pertukaran proton, yang dapat digunakan untuk unit elektrolisis air dan sel bahan bakar, oleh DuPont dan pabrikan lainnya, karena perkembangan di bidang padatan suhu tinggi. oksida dan dengan optimalisasi dan 
rekonstruksi elektrolisis air alkali [3,12]. Perkembangan di dunia saat ini berkontribusi terhadap emisi rumah kaca yang besar gas. Hal ini menyebabkan perdebatan tentang bagaimana membuat proses pembuatan dan teknologi lebih ramah lingkungan. Pikiran seperti ini telah mengilhami beberapa aktor untuk mencari solusi inovatif dengan teknologi baru[4]. Perhatian global yang tren, terhadap penurunan konsumsi bahan bakar dan emisi mesin pembakaran dalam, memotivasi para peneliti untuk mencari solusi alternatif yang tidak memerlukan modifikasi dramatis dalam desain mesin. Di antara solusi tersebut menggunakan $\mathrm{H}_{2}$ sebagai bahan bakar alternatif untuk meningkatkan efisiensi mesin dan menghasilkan polusi yang lebih sedikit [5]. Hidrogen memiliki kecepatan nyala yang lebih tinggi dan campuran bensinnya bisa dibakar lebih cepat. Namun, karena penambahan $\mathrm{H}_{2}$ memperlebar batas mudah terbakar campuran untuk kesetaraan bahan bakar yang lebih ramping, laju reaksi akan berkurang dan pembakaran akan berkepanjangan dalam kondisi ramping[6]. Teknologi ini terfokus hanya untuk mengurangi emisi gas dalam pemakaian bahan bakar pada kendaraan bermotor dan industri, Bahan bakar menggunakan hidrogen sebagai bahan bakar suplemen. Menambahkan a Sejumlah kecil gas hidrogen ke asupan udara dari proses pembakaran bisa mengurangi emisi dan bahan. bakar[15].

Dengan mengunakan teknologi elektrolisis. Teknologi elektrolisis adalah mengunakan suatu perangkat yang disebut Fuel Cell dan HHO Generator gas, dan merupakan alat perangkat yang sederhana dan dapat dibuat, dirancang sesuai kebutuhannya. Tujuan penelitian ini adalah mengaji efisiensi dan daya terhadap alat perangkat generator HHO sederhana berbasiskan elektrolisis dengan skala kecil.

\section{METODOLOGI}

Metode penelitian yang dilakukan dengan cara pengujian terhadap alat perangkat generator HHO. Dimana air dan katalis $\mathrm{NaCHO}_{3}$ (Natrium Bikarbonat) bercampur menjadi cairan elektrolite, dengan perbandingan volume air $0.5,0.75,1,1.25,1.50,1.75,2$ mLdan 1 gram $\mathrm{NaCHO}_{3}$, dan selanjutnya cairan elektrolite tersebut dialirkan ke alat perangkat generator HHO. Alat tersebut mempunyai dua kutup, yaitu kutub positip dan kutub negatif yang dihubungan ke Bateri DC dengan tegangan listrik searah 12 Volts. Jenis alat perangkat generator HHO terbuat dari 10 lembar plat dari bahan Stainless Steel type 316L dengan volume air pada perangkat tersebut adalah $471 \mathrm{~mL}$. Varian yang diamati adalah volume air dan arus listrik. Searah DC. Elektrolisis adalah metode dimana reaksi kimia dilakukan oleh bagian arus listrik melalui larutan elektrolit atau melalui cairan cair garam.senyawa kimia yang saat dilelekan atau dilarutkan pelarut tertentu, biasanya air, akan melakukan curren listrik. Teknik elektrokimia dasar untuk analisis kuantitatif larutan yang mengandung bahan yang dapat teroksidasi atau yang dapat direduksi, pengukuran didasarkan pada berat material yang dilapisi ke elektroda[7,13].

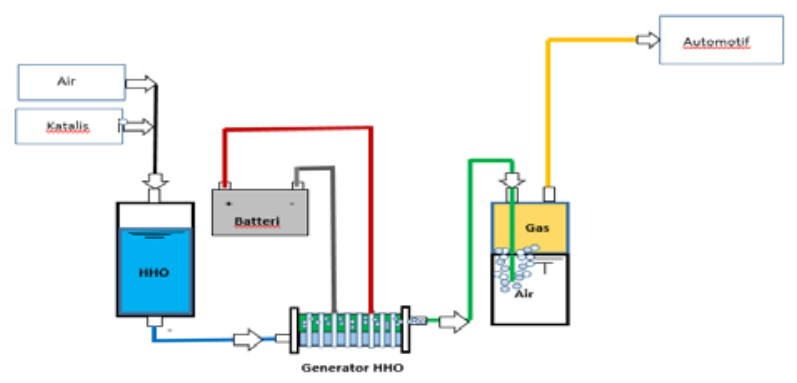

Gambar 1. Sistem instalasi penelitian produksi gas pada alat perangkat generator HHO.

HHO populer dan gas biasa dihasilkan elektrolisis. Ini benar-benar kombinasi dari dua gas hidrogen $\mathrm{H}_{2}$ dan Oksigen $\mathrm{O}_{2}$. Sederhana persamaan kimia untuk konversi air (cairan) ke $\mathrm{HHO}$ (gas) dapat ditulis sebagai $\mathrm{H}_{2} \mathrm{O}_{\text {(l) }}$

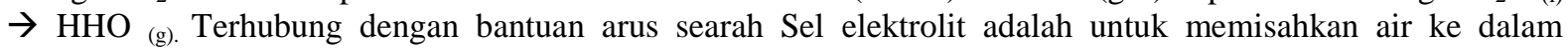
hidrogen dan oksigen.

$2 \mathrm{H}_{2} \mathrm{O}+$ Energi $\rightarrow 2 \mathrm{H}_{2}+\mathrm{O}_{2}$. Proses kimia bisa dengan mudah cepat naik dengan menggunakan katalisator dan selama proses Senyawa terpilih tidak mengubah propertinya. Tujuan utama katalis adalah untuk mengurangi jumlah energi yang dibutuhkan untuk konversi. Itu berikut persamaan kimia menggambarkan fungsi katalis.

$2 \mathrm{H}_{2} \mathrm{O}+$ Catalis + Energi $\rightarrow 2 \mathrm{H}_{2}+\mathrm{O}_{2}+$ Catalis. Akibatnya, Hidrogen $\left(\mathrm{H}_{2}\right)$ serta oksigen $\left(\mathrm{O}_{2}\right)$ akan diproduksi saat membelah air. Secara kimia proses berikut sedang berlangsung elektrolysis.

$2 \mathrm{H}_{2} \mathrm{O} \rightarrow 2 \mathrm{H}_{2}+\mathrm{O}_{2} \cdot[8]$. 


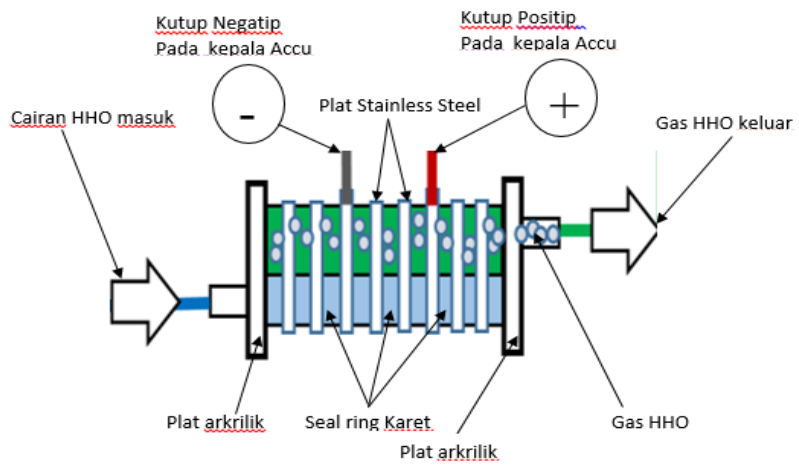

Gambar 2. Sistem skematik aliran generator $\mathrm{HHO}$

Elektrolisis adalah suatu proses penguraian molekul air $\left(\mathrm{H}_{2} \mathrm{O}\right)$ menjadi Hidrogen $\left(\mathrm{H}_{2}\right)$ dan Oksigen $\left(\mathrm{O}_{2}\right)$ dengan energi pemicu reaksi berupa energi listrik. Proses ini dapat berlangsung ketika dua buah elektroda ditempatkan dalam air dan arus searah dilewatkan diantara dua elektroda tersebut. Hidrogen terbentuk pada katoda, sementara Oksigen pada anoda. Selama ini elektrolisis dikenal sebagai proses produksi Hidrogen dari air yang paling efektif dengan tingkat

kemurnian tinggi, tapi terbatas untuk skala kecil. Reaksi yang terjadi adalah sebagai berikut [7,9] :

Anoda $: 2 \mathrm{OH}^{-} \rightarrow 1 / 2 \mathrm{O}_{2}+\mathrm{H}_{2} \mathrm{O}+2 \mathrm{e}^{-}$

Katoda $: 2 \mathrm{H}_{2} \mathrm{O}+2 \mathrm{e}^{-} \rightarrow \mathrm{H}_{2}+2 \mathrm{OH}^{-}$

Total reaksi: $\mathrm{H}_{2} \mathrm{O} \rightarrow \mathrm{H}_{2}+1 / 2 \mathrm{O}_{2}$

Elektrolisis saluran air biasa yang menghasilkan campuran oksigen hidrogen yang ondemand untuk injeksi ke mesin pembakaran dalam banyak dipromosikan sebagai metode untuk meningkatkan jarak tempuh dan mengurangi emisi. Campuran gas ini sering disebut sebagai gas Brown atau HHO. Tujuan buku ini adalah untuk melaporkan hasil penelitian saya tentang gas ini[10]. Metode produksi hidrogen yang lebih murah yaitu proses elektrolisis. Gas HHO dihasilkan oleh proses elektrolisis air. Gas hidrokarbon dihasilkan dengan proses elektrolisis berbagai elektrolit dengan berbagai desain elektroda pada generator hidrogen. Dalam percobaan ini digunakan hidrogen pada laju alir konstan[11].

Posisi vertikal

Tidak memerlukan perawatan khusus. Asupan air terhubung di bagian bawah dan output HHO akan berada di atas sel, dan hanya perlu memastikan bahwa selang keluaran HHO selalu berada di atas bagian atas sel. Jika tidak, gas HHO akan mengalami kesulitan bergerak di luar sel dan produksinya akan berkurang[14].

Posisi horisontal

Membutuhkan perawatan lebih dalam pemasangan. Sel harus diposisikan tegak lurus dan diratakan ke tanah dengan alat kelengkapan tabung menghadap langsung ke langit. Jika Anda melihat dengan hati-hati sel memiliki 2 bukaan, satu lebih tinggi dari yang lain. Pembukaan bawah adalah untuk intake air dan pembukaan atas untuk keluaran gas HHO. Kita harus memastikan bahwa sel tidak ditempatkan dengan sudut / rotasi yang mengurangi jarak antara kedua bukaan. Silakan lihat gambar di bawah ini[14].

Memposisikan Tangki Air

Pastikan tangki air dipasang dengan perawatan yang sama seperti yang dijelaskan sebelumnya untuk generator. Tangki air perlu diutamakan ditempatkan $20 \mathrm{~cm}$ di atas sel kering HHO untuk mencapai kepala gravitasi yang dibutuhkan agar air / hidrogen mengalir ke generator[14].

Memposisikan Bubbler

Bubbler akan melayani dua tujuan: membersihkan gas HHO dan bertindak sebagai penghalang pengaman. Ketika gas HHO dihasilkan dari sel kering, beberapa uap air kecil juga diproduksi karena air akan sedikit panas dengan arus yang mengalir. Uap air ini bisa membawa partikel elektrolit kecil yang bisa menyebabkan korosi yang merusak. Saat gelembung HHO menaikkan kolom air di dalam bubbler, mereka "menggosok" partikel elektrolit yang menempel pada uap air. Hasilnya gas HHO jauh lebih bersih. Jika terjadi kilas balik, bubbler juga bertindak sebagai penghalang keselamatan. Jika api mencapai bubbler dan menyulut HHO yang terakumulasi di atas, kolom air akan mencegah HHO keluar dari sel kering karena nyala api tidak bisa lepas dari gelembung hingga gelembung. Pastikan bubbler dipasang di atas tangki air untuk mencapai kepala gravitasi yang dibutuhkan agar benar "penyaringan" gas HHO[14]. 
Posisi terhadap susunan plat.

Tidak semua lempeng dihubungkan karena elektrolisis akan, dalam hal ini, sangat kuat dan merusak permukaan plat. Plat harus dirancabg agar plat dapat meninggalkan antara yang positif (+) dan negatif (-) beberapa plat tanpa sambungan - Pelat netral - untuk memecahkan voltase dan meningkatkan efisiensi elektrolisis dengan sedikit produksi panas. Sehinga plat dapat dikoneksikan ke kabel sel kering menggunakan tegangan 12v[14].

Kinerja generator HHO mengunakan proses elektrolisis dipengaruhi oleh beberapa parameter, diantaranya sebagai berikut :

1. Laju produksi gas HHO, ditentukan dengan persamaan-1.

$\mathrm{Q}_{\text {Hно }}=$ Vgas $\mathrm{HHO} / \mathrm{t}[\mathrm{ml} / \mathrm{s}]$.

Dimana :

$\mathrm{QHHO}=$ Laju produksi gas $\mathrm{HHO}[\mathrm{ml} / \mathrm{s}]$

Vgas HHO = Volume gas HHO yang dihasilkan [ml]

$\mathrm{t}=$ Waktu yang dibutuhkan untuk menghasilkan gas HHO [s]

2. Efisiensi generator HHO atau proses elektrolisis ditentukan dengan persamaan-2.

Dimana:

$\mathrm{Q}_{\mathrm{HHO}}=$ Laju produksi gas $\mathrm{HHO}$

$\rho_{\mathrm{HHO}}=$ Densitas gas $\mathrm{HHO}(\mathrm{kg} / \mathrm{m} 3)$

$\mathrm{LHV}_{\mathrm{HHO}}=$ Low heating Value gas HHO $(\mathrm{J} / \mathrm{kg})$

\section{HASIL DAN PEMBAHASAN}

Sifat gas HHO Oxy-hydrogen akan terbakar bila dibawa ke adalah suhu pengapian otomatis. Untuk campuran stoikiometri pada tekanan atmosfir normal, pengapian otomatis terjadi pada sekitar 570 (1065 f). Energi minimum yang dibutuhkan energi yang dibutuhkan untuk menyalakan campuran semacam itu dengan percikan sekitar 20 joule mikro. Pada suhu dan tekanan normal, oxy-hydrogen bisa terbakar saat berada di antara sekitar 4\% dan hidrogen 95\% volume[12].

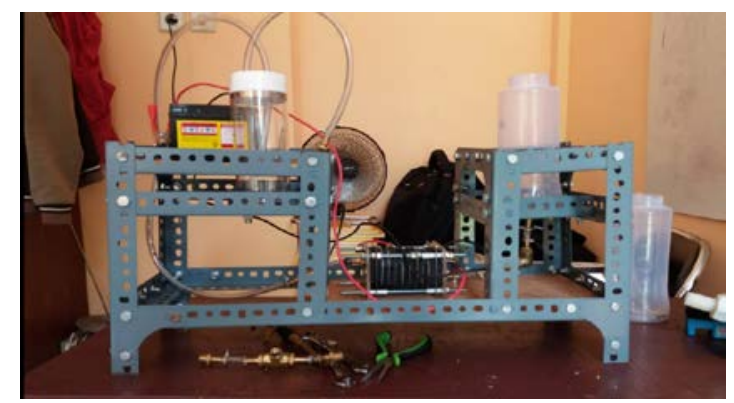

Gambar 3. Konstruksi penelitian perangkat generator $\mathrm{HHO}$

Teknik elektrokimia dasar untuk analisis kuantitatif larutan yang mengandung bahan yang dapat teroksidasi atau yang dapat direduksi, Pengukuran didasarkan pada berat material yang dilapisi ke elektroda[13]. Sel elektrolitik Sel yang terdiri dari elektroda yang direndam dalam elektrolit solusi, untuk melakukan elektrolisis. Potensi elektrolitik Perbedaan potensial antara elektrode dan elektrolit yang berdekatan, dinyatakan dalam beberapa elektroda standar perbedaan.

Menurut prinsip disosiasi elektrik, karena penambahan energy atau pengenceran, molekul senyawa kimia dapat memecah menjadi ion. Hal ini menyebabkan ion memiliki konduktivitas listrik yang lemah, tetapi dapat mencairkan dan meningkatkan listrik sampai batas tertentu, dan diluar itu stagnan. Ini menjelaskan adanya sebuah jendela kecil yang optimal, ketika menemukan konsentrasi larutan yang tepat[19].Kami memantau tegangan dan aliran arus listrik terhadap gelembung-gelembung pada alat perangkat generator HHO, dan tidak melakukan eksperiment terhadap suhu, sehingga dapat melihat beberapa perubahab dalam kinerja, dan dapat menilai keefektivitasan unit pada konsentrasi tertentu. Nilai dari besaran tersebut dapat di lihat pada Tabel.1. 
Tabel 1. Hasil akhir data penelitian.

\begin{tabular}{|c|c|c|c|}
\hline $\begin{array}{c}\text { Konsentrate } \\
\text { Elektrolite(l) }\end{array}$ & $\begin{array}{c}\text { Energi } \\
(\mathrm{Wh} / \mathrm{l})\end{array}$ & $\begin{array}{c}\text { Qhho } \\
(\mathrm{mL} / \mathrm{s})\end{array}$ & $\begin{array}{c}\text { Daya } \\
(\mathrm{W})\end{array}$ \\
\hline 0.5 & 0.06 & 10.45 & 12.9 \\
\hline 0.75 & 0.09 & 15.67 & 19.7 \\
\hline 1 & 0.12 & 20.89 & 26.19 \\
\hline 1.25 & 0.15 & 26.12 & 32.91 \\
\hline 1.5 & 0.18 & 31.34 & 39.4 \\
\hline 1.75 & 0.21 & 36.56 & 46.12 \\
\hline 2 & 0.24 & 41.79 & 78.36 \\
\hline
\end{tabular}

Unsur dari katalis yang dipergunakan adalah $\mathrm{NaCHO}_{3}$, yang mana larutan tersebut dilarutkan dalam pelarut $\mathrm{H}_{2} \mathrm{O}$ menjadi suatu larutan elektrolite senyawa. Larutan elektrolite senyawa ini dapat menghantarkan arus listrik, menurut Michael Faraday bahwa elektrolite mmerupakan suatu zat yang dapat menghantarkan listrik jika berada dalam bentuk larutan[7,16]. Larutan elektrolite dalam air terdisosiasi kedalam partikel-partikel bermuatan listrik positif dan negatif yang disebut ion (ion positif dan ion negatif) Jumlah muatan ion positif akan sama dengan jumlah muatan ion negatif, sehingga muatan ion dalam larutan netral. Ion-ion inilah yang bertugas menghantarkan arus listrik. Dengan perbandingan air dan katalis, dimana semakin banyaknya volume air dan jumlah nya $\mathrm{NaCHO}_{3}$, maka dibutuhkan waktu yang cukup atau durasi tertentu untuk dapat melarutkan larutan eletrolite sebagai penhantar arus listrik. Dengan semakin banyaknya kandungan NaHCO3 (Natrium Bikarbonat) dalam air, maka air tersebut semakin besar dalam menghantarkan arus listri[7,17]. semakin banyak kandungan NaHCO3 (Natrium Bikarbonat) dalam air akan membuat larutan elektrolit semakin jenuh/larutan semakin pekat[7,18]. (Gambar.4 \& 5.).

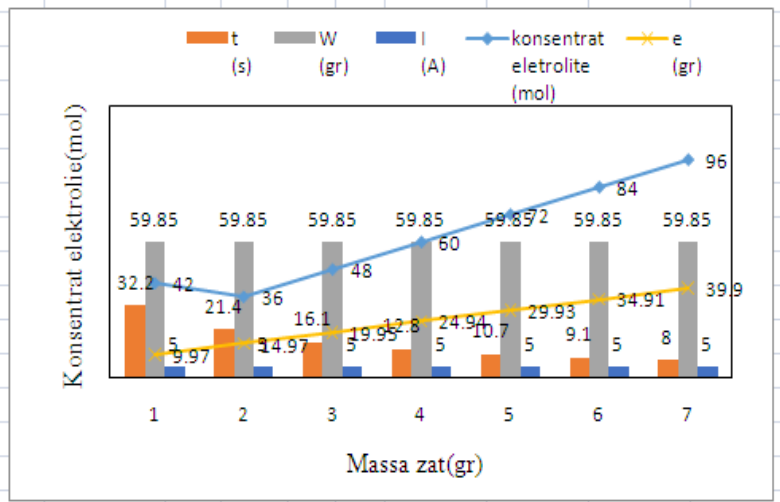

Gambar 4.Grafik Properti $\mathrm{NaCHO}_{3}$

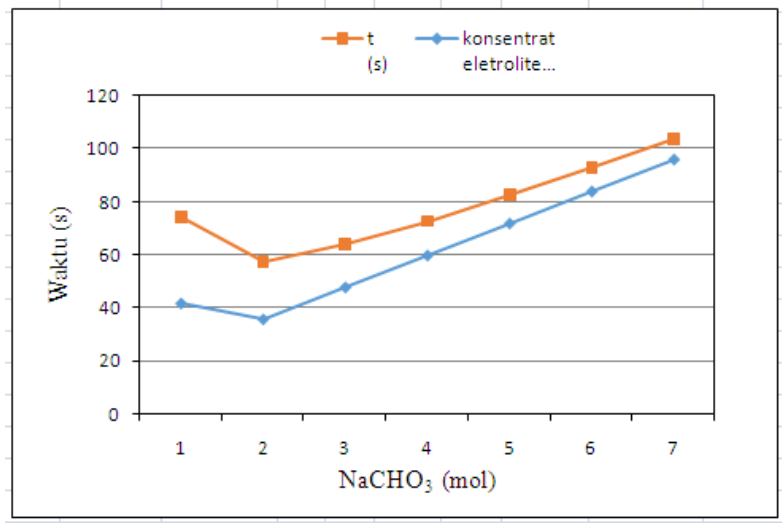

Gambar 5. Grafik hubungan $\mathrm{NaCHO}_{3}$ terhadap waktu 
Berbagai macam bahan digunakan sebagai elektroda. Setiap logam memiliki tingkat aktivitas yang berbeda, hambatan listrik dan resistivitas korosi. Popularitas ini merupakan hasil dari kisaran harga memuaskan, ketahanan korosi dan stabilitas kimia[21,22]. Alat perangkat generator HHO dirancang dan dibuat dari bahan plat Stainless Steel type 316L. Plat elektrolisis type ini banyak dipergunakan karna tahan terhadap korosi. Dengan generator sel kering, mengingat permukaan pelat di unit, kita bisa menggunakan lebih sedikit elektrolit dibandingkan dengan sel basah. Oleh karena itu, volume dan berat sel lebih kecil. Sebagai koneksi elektronik di bawah air masuk Model sel basah, permukaannya perlahan akan terkorosi oleh elektrolit. Di sel HHO, koneksi berada di luar, sehingga tidak berkarat. [26] Mengejutkan dan menggunakan lubang kecil meminimalkan kerugian efisiensi karena kebocoran arus antar sel, namun membuat pengisian ulang elektrolit dan tingkat pemerataan secara signifikan lebih mudah[20.21]. Jika bahan elektroda tidak berpartisipasi secara langsung dalam reaksi elektroda, ini disebut elektroda acuh tak acuh (misalnya elektroda grafit). Oksidasi terjadi pada anoda, elektroda lainnya adalah katoda, dimana reduksi terjadi. Dalam proses elektrolisis, jika ada lebih dari satu jenis reaksi elektrik yang mungkin, maka anion sederhana akan melepaskan bentuk anoda positif (misalnya klorida), yang kekurangan anion ini, OH- akan dibuat dengan pemisahan air. [23].Dengan generator sel kering, mengingat permukaan pelat di unit, kita bisa menggunakan lebih sedikit elektrolit dibandingkan dengan sel basah. Oleh karena itu, volume dan berat sel lebih kecil.Seiring koneksi elektronik di bawah air dalam model sel basah, permukaannya perlahan akan terkorosi oleh elektrolit. Di sel HHO, koneksi berada di luar, sehingga tidak berkarat[19].Konsumsi bahan bakar untuk uji dinamometer HHO dilakukan dengan menimbang wadah bahan bakar, menjalankan mesin dengan jumlah waktu tertentu pada kecepatan dan beban tertentu, menimbang wadah bahan bakar lagi dan menghitung selisihnya untuk mendapatkan bobot bahan bakar yang digunakan selama masa uji. . Bobot adalah dasar yang lebih baik dari pada volume karena berat umumnya dapat diukur dengan lebih akurat dan tepat. Juga, jumlah bahan bakar dalam volume tertentu dipengaruhi oleh suhu sedangkan ini jauh lebih kecil dari pada kasus dengan pengukuran berat. Pengukuran berat yang sangat tepat akan memperhitungkan efek daya apung udara di sekitarnya. Ini tidak perlu dalam kasus pengujian yang dilakukan di Fox Valley Technical College dan Purdue University[10].Dengan generator sel kering, mengingat permukaan pelat di unit, kita bisa menggunakan lebih sedikit elektrolit dibandingkan dengan sel basah. Oleh karena itu, volume dan berat sel lebih kecil. Seiring koneksi elektronik di bawah air dalam model sel basah, permukaannya perlahan akan terkorosi oleh elektrolit. Di sel HHO, koneksi berada di luar, sehingga tidak berkarat[19].(Gambar-6).

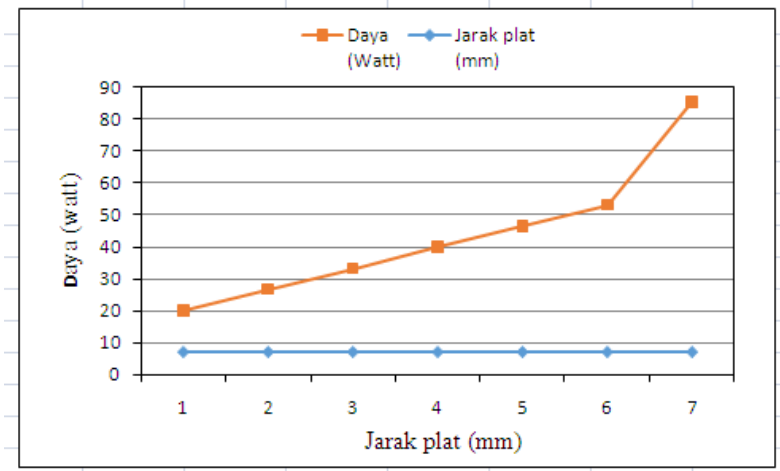

Gambar 6. Grafik hubugan plat terhadap daya

Secara umum terlihat bahwa laju produksi gas HHO (Brown,s Gas) naik seiring bertambahnya prosentase NaHCO3 (Natrium Bikarbonat), hal ini terjadi karena dengan bertambahnya prosentase NaHCO3 (Natrium Bikarbonat) menyebabkan larutan elektrolit semakin banyak mengandung anion dan kation dari NaHCO3 (Natrium Bikarbonat). Dengan semakin banyaknya anion dan kation yang terkandung dalam larutan elektrolit akan menyebabkan larutan elektrolit semakin besar menghantarkan arus listrik dan semakin banyak pula energi listrik yang dapat digunakan untuk melakukan reaksi elektrolisis[24].Sehingga semakin banyak pula molekul air yang terelektrolisis dan gas HHO yang dihasilkan juga akan semakin meningkat. Prosentase NaHCO3 yang terus ditingkatkan dalam larutan elektrolit akan menyebabkan larutan elektrolit semakin jenuh, sehingga anion dan kation dalam larutan elektrolit juga semakin sulit untuk bergerak didalam larutan ketika menghantarkan arus listrik, karena jarak antara partikel terlalu dekat. Sehingga daya hantarnya menjadi rendah dan reaksi elektrolisis yang terjadi tidak akan optimal, dan peningkatan laju produksi gas HHO cenderung menurun[7]. Gas hidrogen, dengan kerapatan 0,00523 lb / ft3, memiliki berat jenis 0,0696 dan dengan demikian kira-kira 7\% densitas udara. Untuk cairan, air (dengan kerapatan 62,4 lb / ft3; 1000 kg / m3) digunakan sebagai bahan referensi, sehingga memiliki berat jenis 1,0 yang relatif terhadap dirinya sendiri. Seperti halnya gas, 
cairan dengan berat jenis lebih besar dari 1,0 lebih berat daripada air. berat jenis kurang dari 1.0 lebih ringan dari air. Hidrogen cair, dengan kerapatan $4.432 \mathrm{lb} / \mathrm{ft} 3$, memiliki berat jenis spesifik 0,0708 dan dengan demikian kira-kira (dan secara bersama-sama) 7\% densitas air. Bila digunakan sebagai bahan bakar kendaraan, kepadatan hidrogen yang rendah mensyaratkan bahwa sejumlah besar hidrogen dibawa untuk memberikan jarak pengaman yang memadai[25]. Jumlah gas yang dihasilkan per satuan waktu berhubungan langsung dengan arus yang melewati sel elektrokimia[29].Resistansi pada plat-plat elektrolisis terkait dengan cakupan gelembung semua permukaan karena akumulasi gelembung gas pada setiap permukaan akan mengurangi konduktivitasnya. Oleh karena itu, ini menyebabkan tingkat penurunan tegangan yang lebih tinggi. Diameter gelembung tergantung pada kerapatan, suhu dan tekanan arus. Nilai tekanan memiliki korelasi terbalik dengan ukuran gelembung dimana kerapatan arus dan suhu berlawanan mempengaruhi [1]. Elektrolit harus ditambahkan ke air pada saat pertama kali menggunakan sistem ini, dan juga saat mengisi ulang, namun dalam jumlah yang lebih rendah. Amper harus diukur untuk memastikan kondisi operasi yang tepat sesuai konsentrasi elektrolit yang digunakan, dalam sistem HHO bergantung pada jenis elektrolit dan kemurnian produk. Elektrolit terbaik semakin banyak elektrolit yang ditambahkan ke air, semakin banyak ampere yang dimiliki di sistem dan juga lebih banyak gas HHO akan diproduksi. Tapi, salah jika berasumsi bahwa produksi gas HHO yang lebih tinggi akan berarti penghematan bahan bakar yang lebih tinggi. Ada titik optimal untuk semua mesin pembakaran dalam[14](Gambar-7).

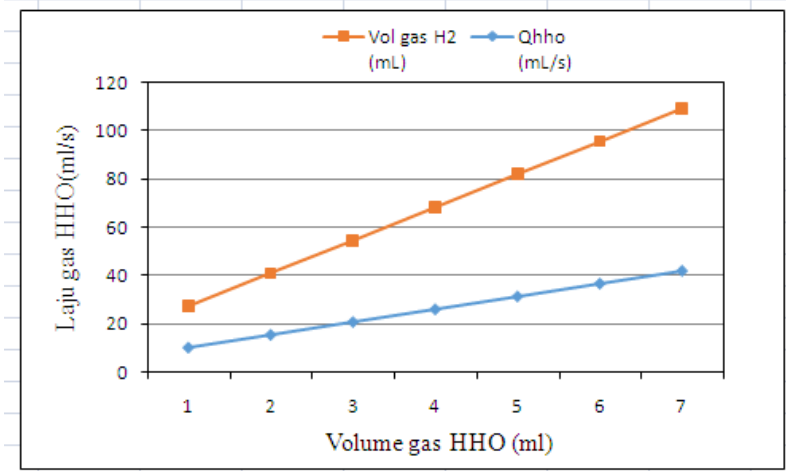

Gambar 7. Grafik hubugan Volume dan Laju gas HHO

Inti dari unit elektrolisis adalah sel elektrokimia, yang diisi dengan air murni dan memiliki dua elektroda yang terhubung dengan catu daya eksternal. Pada tegangan tertentu, yang disebut tegangan kritis, antara kedua elektroda, elektroda mulai menghasilkan gas hidrogen pada elektrode elektrode negatif dan gas oksigen pada elektroda bias positif[29]. Karena volume $1 \mathrm{~kg} \mathrm{H} 2$ negara standar adalah 12474 l, jumlah energi yang dibutuhkan untuk menghasilkan 1 liter hidrogen adalah: $\mathrm{q}=\mathrm{z} \cdot \mathrm{F} \cdot \mathrm{M}(\mathrm{As} / \mathrm{mol})$ atau $(\mathrm{Ah} / \mathrm{kg}) \ldots . . .(1)$, dan $\mathrm{W}_{\mathrm{H} 2}=\mathrm{q} \mathrm{E}_{\mathrm{mF}}(\mathrm{Wh} / \mathrm{kg}) \ldots . . .(2)$. Untuk memiliki 1 liter hidrogen, kita membutuhkan gas HHO 1,5 liter.

Untuk menghasilkan 1 liter gas HHO (0,667 l hidrogen) diperlukan banyak energi adalah:

$\mathrm{W}_{\mathrm{H} 2}=\mathrm{q} \mathrm{E} \mathrm{E}_{\mathrm{Mf}} / 12474(\mathrm{Wh} / \mathrm{l}) \ldots \ldots$...(3)[26].

Kami mengukur unit pada 7 konsentrasi elektrolit yang berbeda, pada arus sama. Kami memeriksa tegangan pada pelat dan jumlah gas yang dihasilkan melalui elektrolisis. Tegangan disolusi air pada suhu $25^{\circ} \mathrm{C}$ (ruangan suhu) adalah 1,23 V (EMF), suhu koefisien adalah $-0,85 \mathrm{mV} / \mathrm{K}$, artinya pada $100^{\circ} \mathrm{C}$ tegangan ini turun menjadi 1.17V. [26,27] Karena itu, di Cahaya data ini, permintaan energi spesifik untuk membuat hidrogen melalui elektrolisis pada suhu $25^{\circ} \mathrm{C}$ dihitung dengan cara berikut [29]. Dari sejumlah sebelas pelat elektroda, dan sembilan elektroda netral tidak memiliki sambungan listrik pada keduanya. Potensi dibagi antara pelat netral sesuai pembagian tegangan dalam rangkaian sambungan. Itu berarti bahwa tegangan antara dua elektroda adalah yang keempat dan tujuh dari tegangan pada satu blok utuh. Dalam percobaan kami, kami memiliki satu blok unit yang terhubung langsung pada baterai DC12V. Kami memperkirakan bahwa Volume air 2liter dan 59.85gram.mol adalah di mana disosiasi elektrolitik memungkinkan konduktivitas listrik paling banyak, sehingga pada arus yang lebih tinggi, unit ini akan menghasilkan hidrogen paling banyak.Semakin dekat pelat adalah efisiensi sel yang lebih baik (Gambar-8). 


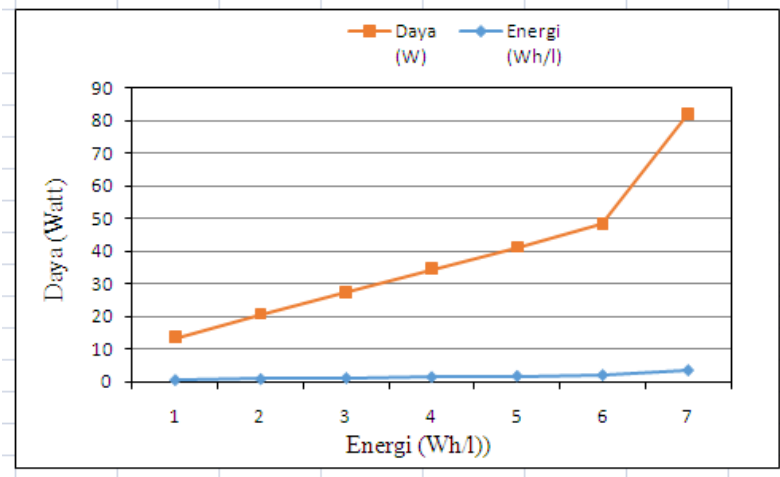

Gambar 8. Grafik hubungan energi terhadap Daya

Efisiensi elektrolisis total menjadi tiga faktor terpisah dan individual: efisiensi listrik, efisiensi elektrolisis dan efisiensi termal. Mereka menghitung pangsa. Mereka menghitung pangsa masing-masing parameter menjadi 70\%, 22\% dan 8\% masing-masing dari total efisiensi. Menurut diskusi mereka, peningkatan suhu sel menyebabkan nilai efisiensi listrik termal dan rendah yang lebih rendah di mana efisiensi elektrolisis tetap ada tanpa perubahan signifikan[25] Serangkaian percobaan dilakukan pada sel kering penghasil gas HHO, apakah kita dapat mengoptimalkannya dengan menemukan konsentrasi elektrolit, nilai arus, dll atau mengubah pengaturan dengan mengubah jarak antara pelat. Larutan eletrolite digunakan, dan unit dipantau dalam beberapa hal, misalnya voltase sel, produksi gas, nilai $\mathrm{ml} / \mathrm{min} / \mathrm{W}$. Puncak efisiensi adalah antara konsentrasi dan semakin banyak arus yang melalui elektrolit, gas tersebut dihasilkan[19].Membuktikan hukum Faraday, dengan mengamati bahwa semakin banyak arus yang kita keluarkan melalui elektrolit, semakin banyak gas yang bisa kita hasilkan. Suhu juga mengubah produksi gas, karena solusi yang lebih panas (semakin banyak mobile adalah ion), semakin banyak gas HHO dikeluarkan[19]. Saat menambahkan gas HHO ke mesin mobil, kita akan melihat ekonomi langsung dalam konsumsi bahan bakar. Namun, ini bukan kasus beberapa kendaraan injeksi bahan bakar elektronik modern yang dilengkapi dengan unit kontrol mesin (ECU), karena bahan bakar yang dibakar di dalam silinder telah meningkat secara signifikan, namun sensor terus memperkirakan jumlah oksigen yang tidak terbakar yang sama untuk keluar dari knalpot mesin[14]. Efisiensi teoritis sel HHO yang dihasilkan adalah 12.5-50\%, sesuai dari jarak plat ke plat dan jenis platnya yang mempunyai beda potensial energi yang ditimbulan arus dari arus listrik.Pada tahun 1977, sebuah studi tentang efek injeksi gas hidrogen botol pada kinerja mesin pengapian percikan dilakukan di Pusat Penelitian Lewis NASA di Cleveland OH. Hasilnya menunjukkan bahwa injeksi hidrogen memang meningkatkan efisiensi mesin asalkan campuran bahan bakar tersebut sangat ramping. Hasil terbaik diperoleh sekitar 70\% rasio stoikiometri[10].Semakin dekat pelat adefisiensi sel yang lebih baik (Gambar-9).

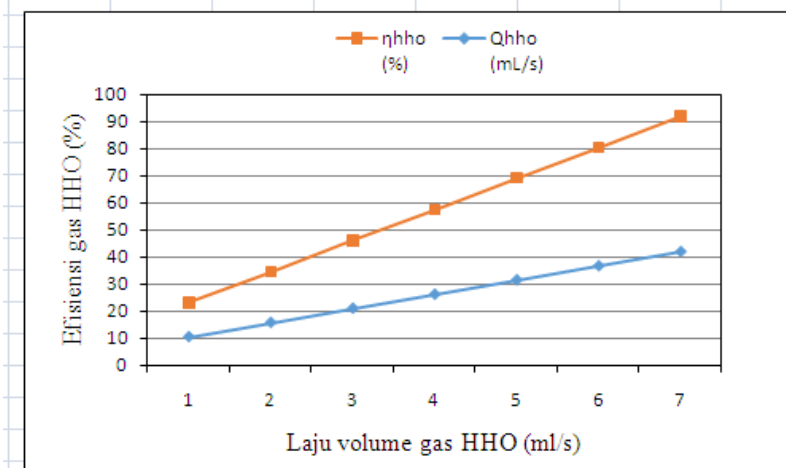

Gambar 9.Grafik efisien produksi HHO dan volume gas 


\section{KESIMPULAN.}

1. Dalam penelitian ini kami telah mengamati jumlah gas HHO saat diberikan hantaran arus listrik, dan jumlah gelembung-gelembung gas produksi HHO yang meningkat pada plat-plat alat perangkat generator. Dengan adanya hantaran arus listrik yang diberikan melalui perangkat generator tersebut, membuat baterai menguras cepat. Sistem elektrolisisi menggunakan katalis dan hantaran arus listrik untuk menghasilkan gas Hidrogen dan Oksigen dari air, dan penghematan bahan bakar yang meningkat karena pembakaran yang lengkap dari kendaraan bahan bakar yang ada. Pengambilan hidroksi ekstrak memisahkan gas Hidrogen dan Oksigen dari air suling dalam wadah stainless steel yang dipasang di dalam kendaraan. menggunakan sedikit energi berlebih untuk memproduksi katalis Hidrogen dengan jumlah yang tepat untuk berbaur dengan sumber bahan bakar yang ada, dan dapat meningkatkan pembakaran dalam pada kendaraan bermotor.

2. Efisien dari perangkat generator $\mathrm{HHO}$, dapat dicapat pada jarak antara plat-plat dan katalis yang dipergunakan. Dari jarak dan sejumlah plat yang digunakan, dan material sebagai elektroda yang menimbulkan reaksi reduksi dan oksidasi, dan terjadinya beda pontensial. Dalam pendekatan yang dilakukan dari jumlah arus mengalir melalui perangkat generator yang membuat baterai menguras cepat, dan dapat mengukur volume dan laju gas HHO, sehingga didapat besaran efisiensi pada bahan bakar hydrogen sebagai campuran dengan bahan bakar hidrokarbon(bensin) dan dapat mengurangi emisi putaran udara, seperti karbon dioksida dan karbon, dll.

\section{DAFTAR PUSTAKA}

[1] Kaveh Mazloomil, Nasri B.Sulaiman, Hossein Moayedi,’Electrical Efficiency of Electrolytic Hydrogen Production”,Department of Electrical and Electronic Engineering, Faculty of Engineering, University Putra Malaysia,Department of Civil Engineering, Estahban Branch, Islamic Azad University, Estahban, Iran.

[2] J. W. Richards, Journal of the Franklin Institute, 152 (1901) 201\&141 (1896) 192

[3] Kreuter W, and Hofmann H, 1998, .Electrolysis: the important energy transformer in a world of sustainable energy., Int. J. Hydrogen Energy 23(8): 661-666.

[4] Sebastian Emanuel son, Jonatan Persson,2007,” Design of a specification of requirements for a fuel cell system for the electric power generation in a 77-foot sailing ship” Department of Energy and Environment, Chalmers University of Technology SE-412 96, Göteborg Sweden

[5] A.Boretti, Comparison of fuel economies of high efficiency diesel and hydrogen engines powering a compact car with a flywheel based kinetic energy recovery systems, Int. J. Hydrogen Energy 35 (2010) 8417-8424.

[6] C. Ji, S. Wang, B. Zhang, Effect of spark timing on the performance of a hybrid hydrogen-gasoline engine at lean conditions, Int. J. Hydrogen Energy 35 (2010) 2203-2212.

[7] Ena Marlina, Slamet Wahyudi, Lilis Yulian”Produksi Brown Gas hasil Elektrolisis H2O dengan katalis NaHCO3”,Jurnal Rekayasa Mesin Vol.4.N0.1,Tahun 2013 53-58,Jurusan Teknik Mesin,Fakultas Teknik Universitas Brawijaya,Malang,Indonesia.

[8] K.Chakrapan, DR.P.Neelamegam,”Optimization of Fuel Consumption using HHO”,In HDL Techhnique verified in FPGA,School of Computing SASTRA University.

[9] Helmenstine A.M., 2001. "Chemistry Glossary Definition of Electroyte”, New York.

[10] "Energy Yield Values and other rationales for improving performance of HHO technology”.Ver.1.2.Energi,March 27, 2011

[11] "Investigasi Eksperimental Rasio Kompresi HHO Gas dan Variasi Kompresi Terhadap Karakteristik Kinerja Mesin Diesel Kecepatan Konstan” IOSR Journal of Mechanical and Civil Engineering (IOSRJMCE) e ISSN: 2278-1684,p-ISSN: 2320-334X, Volume 13, Issue 2 Ver. III (Mar- Apr. 2016), PP 41-47 www.iosrjournals.org

[12] Ap.V.Jose Ananth Vino,”HHO assisted LPG Engine”University

[13] McGraw-Hill,"Dictionary of Chemistry”Second Edition,Handbooks,Copyright,2003,Inc,United States of America.

[14] "HHO Hydrogen on Demand Dual Fuel Generator Systems",HHO Plus, Alternative Energies,Ltd,Technical Department ,Travessa das Serras 33, Vieira de Leiria, Portugal.

[15] Leelakrishnan, N. Lokesh, H.Suriyan,’Performance and emission character of Brown's gas enriched air in spark ignition engine”,Sri Ram Engineering College, Anna University, Chenn.

[16] Hendri Chem,2010.”Kimia Fisika_Daya Hantar Listrik”. Artikel Kimia Daya Hantar Listrik.

[17] Helen Margaret., 2012.”Larutan Elektrolit dan Non Elektrolit”., Tugas Mata Kuliah Kimia Dasar., Universitas Katolik Parahyangan.

[18] S. Hamdani., 2010. "Larutan”., Kumpulan Artikel kimia dan Farmasi.

[19] "Measuring and Optimisation of HHO Dry Cell for energy efficiency", 
University of Pannonia, Faculty of Information Technology, Department of Electrical, Engineering and Information Systems, Veszprém, Egyetem u. 10,Acta Tehnica Corviniensis,Hungary,ISSN 2067-3809.

[20] N. Shimizu, S. Hotta, T. Sekiya and O. Oda, “J. Appl. Electrochem”., 36 (2006) 419.

[21] Kaveh Mazloomi, Nasri b. Sulaiman, Hossein Moayedi,”

Electrical Efficiency of Electrolytic Hydrogen Production”. Department of Electrical and Electronic Engineering, Faculty of Engineering, University Putra Malaysia , Department of Civil Engineering, Estahban Branch, Islamic Azad University, Estahban, Iran, Int. J. Electrochem. Sci., 7 (2012) 3314 - 3326

[21] Kaveh Mazloomi, Nasri b. Sulaiman, Hossein Moayedi,”

Electrical Efficiency of Electrolytic Hydrogen Production”,Department of Electrical and Electronic Engineering, Faculty of Engineering, University Putra Malaysia, Department of Civil Engineering, Estahban Branch, Islamic Azad University, Estahban, Iran, Int. J. Electrochem. Sci., 7 (2012) 3314 3326.

[22] Z.D.Wei,M.B.Ji,S.G.Chen,Y.Liu,C.X.Sun,G.Z.Yin,P.K. Shen and S.H.Chan,Electrochim. Acta, 52 (2007) 3323.

[23] Katharina Wendler, Jens Thar , Stefan Zahn and Barbara Kirchner: Estimating the Hydrogen Bond Energy J. Phys.Chem.A,2010,114(35),pp9529 9536,DOI:10.1021/jp103470e, Publication Date (Web): August 13, 2010, Copyright (C) 2010 American Chemical Society

[24] Meti Marayanti., 2008. "Larutan Elektrolit dan Non Elektrolit”. Bahan ajar., Jurusan Pendidikan Kimia FPMIPA Universitas Pendidikan Indonesia

[25] Hydrogen Fuel Cell Engines” Hydrogen Properties”.

[26] Ammar A. Al-Rousan (2010): Reduction of fuel consumption in gasoline engines by introducing HHO gas into intake manifold. ELSEVIER International Journal of Hidrogen Energy 35 pp.12930-12935

[27] Clyde R. Dillard, David E. Goldberg (1982): Kémia - Reakciók, szerkezetek, tulajdonságok, Gondolat Könyvkiadó, ISBN: 9632807014

[28] Heinz Elbert (1974): Elektrokémia, Müszaki Könyvkiadó, ISBN: 9631005801

[29] Emmanuel Zoulias, Elli Varkaraki, Nicolaos Lymberopoulos, Christodoulos N. Christodoulou, George N. Karagiorgis,”A Review on water electrolysis”,Centre for Renewable Energy Sources (CRES), Pikermi, Greece, Frederick Research Center (FRC), Nicosia, Cyprus

[30] Báder Imre: Alkalmazott elektrokémia, http://www.unimiskolc.hu/ fkmbader/Tudomanyos/Keziratok/Alk eljegyzet.pdf 